\title{
Correlation of Survivin and MMP9 Expressions with Prognosis and Clinicopathological Parameters in Surface Epithelial Ovarian Carcinomas
}

\author{
Overin Yüzey Epitel Karsinomlarında Survivin ve MMP-9 \\ Ekspresyonlarının Klinikopatolojik Parametrelerle ve \\ Prognozla Korelasyonu
}

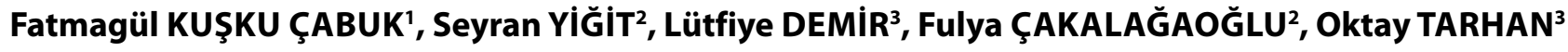 \\ Department of Pathology, 'Izmir Aliağa State Hospital, IZMiR, TURKEY \\ Departments of ${ }^{2}$ Pathology and ${ }^{3}$ Oncology, Katip Çelebi University, İzmir Atatürk Education and Research Hospital, iZMiR, TURKEY
}

\begin{abstract}
Objective: Pathological stage is the most important prognostic factor in ovarian carcinomas, and many studies have been carried out to predict prognosis. In our study, we searched the expression of survivin, which prevents apoptosis and matrix metalloproteinase-9 (MMP-9), which promotes the metastasis of the tumour by splitting up the basal membrane in primary epithelial ovarian carcinomas. We aimed to observe their effects on prognosis by comparing clinicopathological parameters.
\end{abstract}

Material and Method: 60 cases diagnosed with epithelial ovarian carcinoma between 2003 and 2008 and treated and followed up at the oncology clinic were included in the study. 42 patients were serous, 11 endometrioid, 5 mixed type, 1 was clear cell and 1 was undifferentiated adenocarcinoma. Survivin and MMP-9 expression was evaluated in each tumour and assosication with clinicopathological parameters (age, tumour diameter, localisation, histological type of tumour, grade, stage, recurrence and metastasis) were searched and also overall survival and disease free of survival were evaluated.

Results: Survivin was statistically insignificant within the clinicopathological parameters. The correlation between the tumour grade and the staining density of MMP-9 in epithelial cells ( $\mathrm{p}=0.028)$ and the correlation between disease free of survival and MMP-9 expression in stromal cells $(\mathrm{p}=0.0326)$ was significant. When the stage was compered with clinocopathologic parameters; recurrence $(\mathrm{p}=0.005)$ and death rates $(\mathrm{p}<0.001)$ were significantly increased but overall survival $(\mathrm{p}=0.0269)$ was significantly decreased in advanced-stage patients.

Conclusion: In the present study, the stage was found to be an important prognostic parameter in surface epithelial ovarian carcinomas and an association was found between MMP-9 stromal staining and survival.

Key Words: Ovarian neoplasms, MMP-9, Survivin, Prognosis
ÖZ

Amaç: Over kanserlerinde patolojik evre en önemli prognostik faktör olup prognozu öngörme için yapılan pek çok çalışma vardır. Çalışmamızda, survivin gibi apoptozu engelleyen ve matriks metalloproteinaz-9 (MMP-9) gibi bazal membranı parçalayarak tümörün yayılmasını kolaylaştıran belirteçlerin primer epitelyal over karsinomlarında ekspresyonlarını araştırdık. Bunları klinikopatolojik parametrelerle karşılaştırarak prognoza olan etkilerini görmeyi amaçladık.

Gereç ve Yöntem: 2003-2008 yılları arasında epitelyal over karsinomu tanısı alan, onkoloji kliniğinde tedavi ve takip edilen 60 olgu çalışmaya alındı. Hastaların 42'si seröz, 11'i endometrioid, 5'i miks tip, 1'i berrak hücreli, 1'i indifferansiye adenokarsinomdu. Her tümöre uygulanan survivin ve MMP-9 ekspresyonu klinikopatolojik parametreler (yaş, tümör çapı, lokalizasyon, tümörün histolojik tip, derece, evre, nüks ve metastaz) ile ilişkisi araştırıldı. Ayrıca, genel sağkalım ve hastalıksız sağkalım üzerine etkileri değerlendirildi.

Bulgular: Survivin klinikopatolojik parametrelerle istatiksel olarak anlamsızd. MMP-9'un epitelyal hücrelerde boyanma yoğunluğu ile tümör derecesi $(\mathrm{p}=0.028)$ ve MMP-9'un stromal hücrelerde boyanmasının hastalıksız sağ kalım üzerine anlamlı etkisi olduğu saptand $1(p=0.0326)$. Evre ile klinikopatolojik parametreler karşılaşt1rıldığında; ileri evre hastalarda anlamlı olarak rekürrens $(\mathrm{p}=0.005)$ ve ölüm oranı $(\mathrm{p}<0.001)$ daha fazla, genel sağkalım süreleri $(\mathrm{p}=0.0269)$ ise anlamlı olarak kısaydı.

Sonuç: Çalışmamızda, over yüzey epitel karsinomlarında evrenin önemli bir prognostik parametre olduğu ve MMP-9 stromal boyanması ile sağ kalım arasında bir ilişki olduğu bulundu.

Anahtar Sözcükler: Over tümörleri, MMP-9, Survivin, Prognoz

Correspondence: Fatmagül KUŞKU ÇABUK

İstanbul Bilim Üniversitesi, Tip Fakültesi, Patoloji Anabilim Dalı, İZMIR, TURKEY

E-mail: fatmagulkusku@hotmail.com Phone: +90 5056102715 


\section{INTRODUCTION}

Ovarian cancer is the most lethal gyneacological malignancy and ranks 5th in cancer-related women deaths in the USA (1). In spite of advances in treatment during the last 2030 years, there has been no significant decrease in death rate caused by the ovarian cancer and the average 5-year life span has been limited to \% 10-30 (2-5). At present, pathological stage is the most important prognostic factor known in ovarian tumours (6-8).

Numerous markers have been studied with immunohistochemical or cytogenetic methods in order to explore a prognostic and predictive factor in surface epithelial ovarian carcinomas. Survivin and matrix metalloproteinase-9 (MMP-9) are also among the most overemphasized markers in this issue $(9,10)$.

In recent studies, survivin was proven to play a vital role in the invasion and metastases of ovarian epithelial carcinomas $(3,11)$. Survivin (BIRC5: Baculoviral inhibitor of apoptosis repeat-containing 5) belongs to the gene family that inhibits apoptosis and it prevents the apoptosisrelated death of cancer cells $(3,11,12,13)$. While it is not present in many normal cells, its distinct expression in cancer cells is considered an indicator of poor prognosis (9,12-18). Ovarian tumours, with cytoplasmic survivin positivity, were reported to be more resistant to taxol/ platinum treatment (19).

The tumour cells which escape from apoptosis spread to the surface of the ovarian capsule and break up the basal membrane with MMP. This step is an important stage in terms of tumour progression $(3,20)$. MMPs are homologue enzyme family that includes zinc in its active region and has the ability to break up extracellular matrix (ECM) and basal membrane components $(21,22)$. They also take part in pathological processes like tumour cell invasion, angiogenesis and metastasis $(21,22)$. The expression of MMP-9 was detected at a higher rate in ovarian cancers compared to the normal ovarian tissue, benign and borderline tumours (23). Furthermore, its expression was demonstrated in many metastatic ovarian carcinomas $(21,24)$. MMP-9 is expressed in both epithelial and stromal cells of ovarian tumours $(23,24,25,26)$. Both stainings have been associated with poor prognosis $(24,26)$. Particularly stromal staining has been associated with advanced stage, development of metastasis, the presence of ascites and shorter survival times compared to the tumours without stromal expression (23-27).

The purpose of this study is to evaluate the expressions of survivin and MMP-9 with clinicopathological parameters in surface epithelial ovarian carcinomas and to detect their effects on prognosis.

\section{MATERIAL and METHOD}

This study consisted of sixty patients who were diagnosed with epithelial ovarian carcinoma between 2003 and 2008, in Department of Pathology, Izmir Atatürk Training and Research Hospital and had been treated at Department of Medical Oncology of the same hospital and followed-up for at least 1 year. Patients' age, tumour's diameter, localisation, histological type, grade, stage, recurrence, metastatic conditions and the survival data were obtained from the archive records.

The Gyneacologic Oncology Group (GOG) grading system was used in grading the tumours that belonged to the cases and the International Federation of Gyneacology and Obstetrics (FIGO) was used in staging the tumours. The terms disease-free survival (DFS) and overall survival (OS) were used for prognostic evaluation of the patients. DFS was defined as the time from the diagnosis to the disease recurrence or the last visit which came first for early-stage (stage I-II) patients. On the other hand OS was defined as the time from diagnosis to the last visit or death, whichever came first.

Immunohistochemical staining was performed on formalinfixed and parafin embedded tissue using the Streptavidinbiotin complex method. Tissue sections were incubated with primary antibodies anti Survivin (Monoclonal Mouse anti- human Survivin Clone 12C4, Dako Denmark) 1/100 dilution; MMP-9 (MMP-9, 92 kDa Collagenase IV, Epitope Specific Rabbit Antibody, Spring Biosence) ready to be used was applied for $2 \mathrm{~h}$ at room temperature. Normal testis and placenta tissues were used as positive control for survivin and MMP-9 staining respectively.

For immunohistochemical analysis, all the tumour areas were examined at low magnification (x10). For each antibody in the epithelial cells, at x20 magnification, the percantage of stained tumour cells, and at high magnification (x40), the intensity of tumour cells were determined semiquantitatively and subjectively. Immunohistochemical evaluation was performed by modifying the method used in the study of Kamat et al (24). For survivin and MMP-9, cytoplasmic staining in epithelial cells was taken into consideration and the total score was obtained by adding up the values given to staining percentage and intensity. Accordingly, for staining percentage, $0-5 \%=0,6-50 \%=1,50 \%>2$; for staining intensity, weak $=1$, moderate $=2$, strong $=3$ points were given. Overall score was obtained by adding up these points and the following scores was defined: $0=$ negative 
(no staining or if $<5 \%$ regardless of staining density); score $1=$ weak staining (total points 2 ), score $2=$ moderate staining (total points $3-4$ ), and score $3=$ strong staining (total points 5). The expression of each antibody was separated into 2 groups as low (score 0 and 1) and high expression (score 2 and 3) for statistical analysis. Next, each marker was compared to all of the clinicopathological parameters. In addition, stromal expression was evaluated for MMP-9.

For statistical analyses, SPSS (Statistical Package for Social Sciences) version 17.0 program was used. Clinical features were defined by descriptive analysis; median and mean values were calculated. The difference between two variables was sought by $\mathrm{x}^{2}$ (Chi-square) test. Nonparametric test (Kruskal Wallis) was used to compare the effect of a parameter between two multi-sorted variable. Survival analysis was carried out by Kaplan-Meier analysis; all of the ranges were stated with a $95 \%$ confidence interval (CI). The survival comparison between two different parameters was fulfilled by using the Log-rank test. Statistical significance limit was accepted as $\mathrm{p}$ values under 0.05 for all tests.

\section{RESULTS}

In demographic records, the patients' age, tumour's location, diameter, type, grade, stage, metastasis, recurrence and survival status of the patients were evaluated (Table I). Median age was 54.5 (range, 36-80 years). Tumour locations of 59 patients and tumour diameters of 58 patients reached from the records. The median tumour diameter was 9.55 $\mathrm{cm}$ (range, $2.5-25 \mathrm{~cm}), 41,7 \%(\mathrm{n}=25)$ patients had stage I-II disease (early stage) while $58,3 \%$ of patients $(n=35)$ had stage III-IV (advance stage) disease. Histologically 42 of patients were serous, 11 endometrioid, 5 mixed type, 1 was clear cell and 1 was indifferentiated adenocarcinoma. The median follow-up period was 32.46 (range 3-82) months. The median OS was 33.6 ( range $3-54,95 \% \mathrm{CI}$ ) months and DFS was 18.1 (range 6-82, 95\% CI) months. 16,6\% $(n=10)$ of patients daveloped metastasis during the follow-up period. Four patients had liver metastasis, four patients had pleural effusion while one patient developed pancreas and one patients lung metastasis during the follow-up period. No statistical correlation was detected in the comparison between age and stage, tumour diameter, histological type.

Table I: Demographic, clinic and histopathologic features of the patients

\begin{tabular}{|c|c|c|}
\hline \multicolumn{2}{|c|}{ Clinicopathological qualities } & \multirow{2}{*}{$\begin{array}{c}\text { n } \% \\
32(53.3 \%)\end{array}$} \\
\hline & $<55$ & \\
\hline Age & $\geq 55$ & $28(46,6 \%)$ \\
\hline \multirow{3}{*}{ Localisation } & Right & $16(27.1 \%)$ \\
\hline & Left & $14(23.3 \%)$ \\
\hline & Bilateral & $29(49.2 \%)$ \\
\hline \multirow{2}{*}{ Tumour size } & $\leq 10 \mathrm{~cm}$ & $40(68.9 \%)$ \\
\hline & $>10 \mathrm{~cm}$ & $18(31.1 \%)$ \\
\hline \multirow{6}{*}{ Histologic type } & Serous adenocarcinoma & $42(70 \%)$ \\
\hline & Endometrioid adenocarcinoma & $11(18.3 \%)$ \\
\hline & Serous + endometrioid adenocarcinoma & $3(5 \%)$ \\
\hline & Serous + clear-cell adenocarcinoma & $2(3.3 \%)$ \\
\hline & Clear-cell adenocarcinoma & $1(1.7 \%)$ \\
\hline & Undifferentiated adenocarcinoma & $1(1.7 \%)$ \\
\hline \multirow{3}{*}{ Tumour grade } & Well differentiated & $8(13.3 \%)$ \\
\hline & Moderately differentiated & $21(35 \%)$ \\
\hline & Undifferentiated & $31(51.7 \%)$ \\
\hline \multirow{2}{*}{ Tumour stage (FIGO) } & Early stage (IA-IIC) & $25(41.7 \%)$ \\
\hline & Advanced stage (IIIA-IV) & $35(58.3 \%)$ \\
\hline \multirow{2}{*}{ Recurrence } & Present & $31(51.7 \%)$ \\
\hline & Absent & $29(48,3 \%)$ \\
\hline \multirow{2}{*}{ Survival data } & Alive & $31(51,7 \%)$ \\
\hline & Dead & $29(48,3 \%)$ \\
\hline
\end{tabular}


Statistically; histological type, tumour's grade, tumour diameter, stage and age were compared with each other. However, no statistical association was obtained from this comparison. Additionally the effects of these parameters on survival were investigated. Distant metastases rate was significantly higher in advanced stages $(\mathrm{p}=0.005)$ and overall survival of the patients with advanced-stage disease was significantly shorter than that of early stage patients (11 months vs 34 months; 95\% CI; $\mathrm{p}=0.0269$ ). As expected, these results supported the fact that in advanced stage patients, risk of recurrence and death rates increase when OS period decreases.

In immunohistochemical analysis, survivin was positive in 54 cases $(88.3 \%)$ and MMP-9 was positive in 49 cases (76.7\%) (Figure 1, 2). The details of staining analyses for

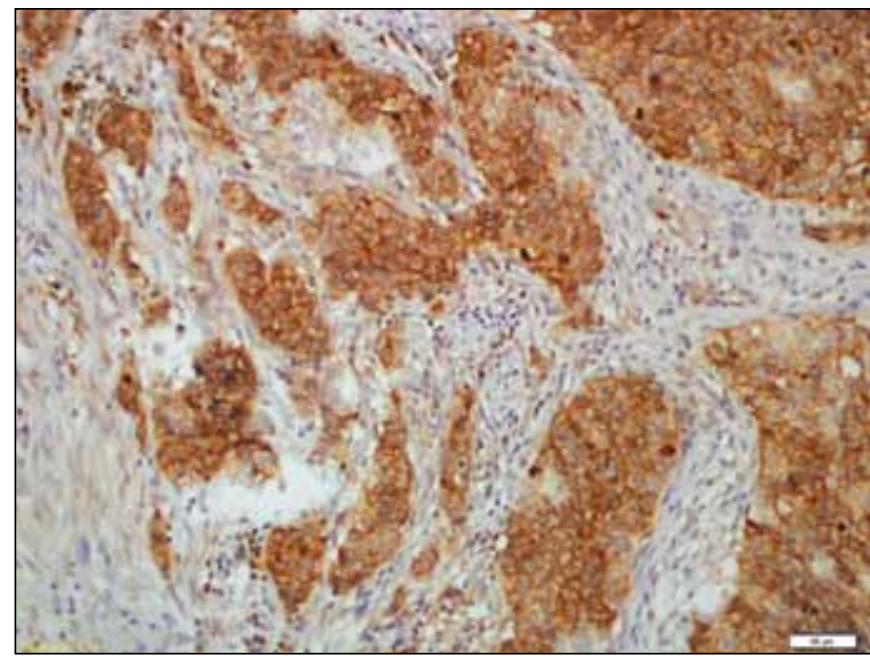

Figure 1: High survivin cytoplasmic expression in serous adenocarcinoma (Survivin x200). survivin and MMP-9 are shown in Table II. Since nuclear and cytoplasmic staining were only detected in four patients with survivin nuclear staining was not reported. Survivin staining percentage, intensity and total score values (poor: 0 and 1, strong: 2 and 3) were compared with stage, grade, histological type and tumor diameter individually, however no statistically significant difference was observed (Table III). Moreover, no significant effect on disease free survival and overall survival was observed as well.

Epithelial staining in MMP-9 was compared with all clinicopathologic parameters like survivin (Table IV). The only significant correlation was detected between the staining intensity of MMP-9 and histological grade $(\mathrm{p}=0.028)$. As tumour grade increase, MMP-9 staining intensity increase as well. Stromal staining with MMP-9

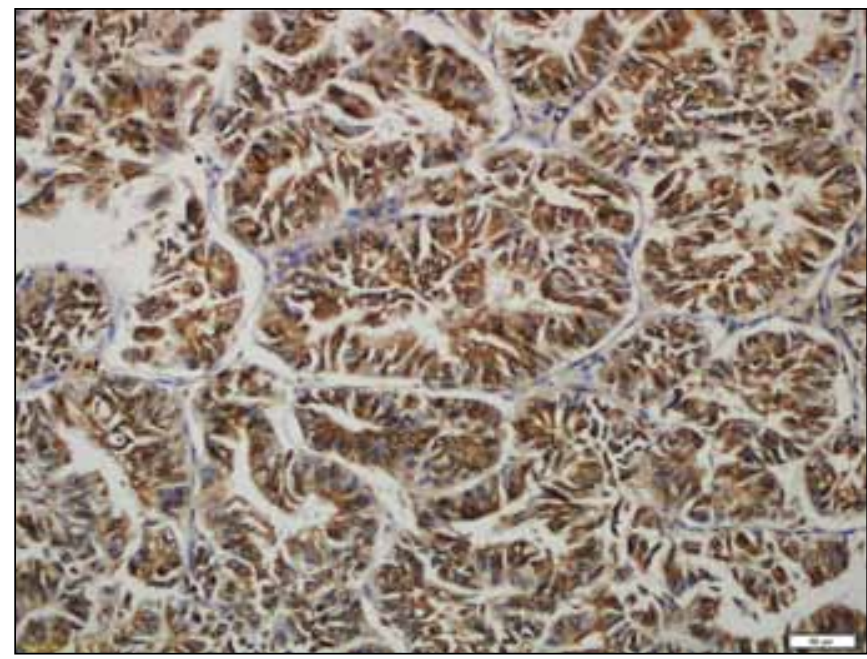

Figure 2: High MMP-9 expression in endometrioid adenocarcinoma (MMP-9 x200).

Table II: Percentage, density and score distribution of Survivin and MMP-9

\begin{tabular}{|l|c|c|c|}
\hline \multicolumn{2}{|c|}{ Survivin and MMP-9 values } & Survivin n (\%) & MMP-9 n (\%) \\
\hline \multirow{4}{*}{ Percentage } & $\leq 5 \%$ & $7(11,7 \%)$ & $14(23,3 \%)$ \\
\cline { 2 - 4 } & $6-50 \%$ & $20(33,3 \%)$ & $9(15 \%)$ \\
\cline { 2 - 4 } & $>50 \%$ & $33(55 \%)$ & $37(61,7 \%)$ \\
\hline \multirow{4}{*}{ Density } & No staining & $6(10 \%)$ & $11(18,3 \%)$ \\
\cline { 2 - 4 } & Weak & $13(21,7 \%)$ & $11(18,3 \%)$ \\
\cline { 2 - 4 } & Moderate & $22(36,6 \%)$ & $17(28,3 \%)$ \\
\cline { 2 - 4 } & Strong & $19(31,7 \%)$ & $11(18,3 \%)$ \\
\cline { 2 - 4 } & Score 0 & $6(10 \%)$ & $3(5 \%)$ \\
\cline { 2 - 4 } & Score 1 & $1(1,7 \%)$ & $12(20 \%)$ \\
\cline { 2 - 4 } & Score 2 & $22(36,7 \%)$ & $34(56,7 \%)$ \\
\cline { 2 - 4 } & Score 3 & $31(51,6 \%)$ & \\
\hline
\end{tabular}


Table III: Comparison of survivin staining percentage, density and scores with clinicopathological parameters

\begin{tabular}{|c|c|c|c|c|c|c|c|c|c|c|}
\hline \multirow[b]{2}{*}{ Survivin values } & \multicolumn{4}{|c|}{ Staining percentage } & \multicolumn{3}{|c|}{ Staining density } & \multicolumn{3}{|c|}{ Score values } \\
\hline & $\begin{array}{l}<5 \% \\
\mathrm{n} / \%\end{array}$ & $\begin{array}{c}6-50 \% \\
\text { n/\% }\end{array}$ & $\begin{array}{c}>50 \% \\
\mathbf{n} / \%\end{array}$ & p value & $\begin{array}{l}\text { Weak } \\
\mathbf{n} / \%\end{array}$ & $\begin{array}{c}\text { Strong } \\
\mathbf{n} / \%\end{array}$ & p value & $\begin{array}{l}\text { Weak } \\
\text { n/\% }\end{array}$ & $\begin{array}{c}\text { Strong } \\
\mathbf{n} / \%\end{array}$ & p value \\
\hline $\begin{array}{l}\text { FIGO stage } \\
\text { Early } \\
\text { Advanced }\end{array}$ & $\begin{array}{l}4 / 16 \\
3 / 8.5\end{array}$ & $\begin{array}{c}9 / 36 \\
11 / 31.4\end{array}$ & $\begin{array}{l}12 / 48 \\
21 / 60\end{array}$ & 0.524 & $\begin{array}{l}10 / 40 \\
9 / 25.7\end{array}$ & $\begin{array}{c}15 / 60 \\
26 / 74.3\end{array}$ & 0.243 & $\begin{array}{l}4 / 16 \\
3 / 8.6\end{array}$ & $\begin{array}{c}21 / 84 \\
32 / 91.4\end{array}$ & 0.337 \\
\hline $\begin{array}{l}\text { Grade } \\
\text { Low } \\
\text { Moderate } \\
\text { High }\end{array}$ & $\begin{array}{c}0 / 0 \\
2 / 9.5 \\
5 / 16.1\end{array}$ & $\begin{array}{c}4 / 50 \\
8 / 38 \\
8 / 25.9\end{array}$ & $\begin{array}{c}4 / 50 \\
11 / 52.5 \\
18 / 58.1\end{array}$ & 0.640 & $\begin{array}{l}3 / 37.5 \\
8 / 38.1 \\
8 / 25.8\end{array}$ & $\begin{array}{c}5 / 62.5 \\
13 / 61.9 \\
23 / 74.2\end{array}$ & 0.631 & $\begin{array}{c}0 / 0 \\
2 / 10 \\
5 / 16.1\end{array}$ & $\begin{array}{c}8 / 100 \\
19 / 90 \\
26 / 83.9\end{array}$ & 0.631 \\
\hline $\begin{array}{l}\text { Type } \\
\text { Serous } \\
\text { Endometrioid } \\
\text { Mixed }\end{array}$ & $\begin{array}{c}5 / 11.4 \\
2 / 18.2 \\
0 / 0\end{array}$ & $\begin{array}{c}15 / 34.1 \\
3 / 27.3 \\
2 / 40\end{array}$ & $\begin{array}{c}24 / 54.5 \\
6 / 54.5 \\
3 / 60\end{array}$ & 0.929 & $\begin{array}{c}15 / 34.1 \\
4 / 36.7 \\
0 / 0\end{array}$ & $\begin{array}{c}29 / 65.9 \\
7 / 63.6 \\
5 / 100\end{array}$ & 0.372 & $\begin{array}{c}5 / 11.4 \\
2 / 18.2 \\
0 / 0\end{array}$ & $\begin{array}{c}39 / 88.6 \\
9 / 81.8 \\
5 / 100\end{array}$ & 0.799 \\
\hline $\begin{array}{l}\text { Tumor size } \\
\leq 10 \mathrm{~cm} \\
>10 \mathrm{~cm}\end{array}$ & $\begin{array}{l}5 / 12.5 \\
2 / 11.1\end{array}$ & $\begin{array}{l}14 / 35 \\
6 / 33.3\end{array}$ & $\begin{array}{l}21 / 52.5 \\
10 / 55.6\end{array}$ & 0.999 & $\begin{array}{l}12 / 30 \\
7 / 38.9\end{array}$ & $\begin{array}{c}28 / 70 \\
11 / 61.1\end{array}$ & 0.505 & $\begin{array}{l}5 / 12.5 \\
2 / 11.1\end{array}$ & $\begin{array}{l}35 / 87.5 \\
16 / 88.9\end{array}$ & 0.881 \\
\hline $\begin{array}{l}\text { Distant } \\
\text { metastasis } \\
\text { Absent } \\
\text { Percent }\end{array}$ & $\begin{array}{l}6 / 12 \\
1 / 10\end{array}$ & $\begin{array}{l}18 / 36 \\
2 / 20\end{array}$ & $\begin{array}{c}26 / 52 \\
7 / 70\end{array}$ & 0.701 & $\begin{array}{c}17 / 34 \\
2 / 20\end{array}$ & $\begin{array}{c}33 / 66 \\
8 / 80\end{array}$ & 0.480 & $\begin{array}{l}6 / 12 \\
1 / 10\end{array}$ & $\begin{array}{c}44 / 88 \\
9 / 90\end{array}$ & 1.000 \\
\hline
\end{tabular}

Table IV: Comparison of MMP-9 staining percentage, density and scores with clinicopathological parameters

\begin{tabular}{|c|c|c|c|c|c|c|c|c|c|c|}
\hline \multirow[b]{2}{*}{ MMP-9 values } & \multicolumn{4}{|c|}{ Staining percentage } & \multicolumn{3}{|c|}{ Staining density } & \multicolumn{3}{|c|}{ Score values } \\
\hline & $\begin{array}{l}<5 \% \\
\mathbf{n} / \%\end{array}$ & $\begin{array}{c}\text { 6-50\% } \\
\mathbf{n} / \%\end{array}$ & $\begin{array}{c}>50 \% \\
\mathbf{n} / \%\end{array}$ & $p$ value & $\begin{array}{l}\text { Weak } \\
\text { n/\% }\end{array}$ & $\begin{array}{c}\text { Strong } \\
\mathbf{n} / \%\end{array}$ & $p$ value & $\begin{array}{c}\text { Weak } \\
\mathbf{n} / \%\end{array}$ & $\begin{array}{c}\text { Strong } \\
\mathbf{n} / \%\end{array}$ & $p$ value \\
\hline $\begin{array}{l}\text { FIGO stage } \\
\text { Early } \\
\text { Advanced }\end{array}$ & $\begin{array}{c}5 / 20 \\
9 / 25.7\end{array}$ & $\begin{array}{c}5 / 20 \\
4 / 11.4\end{array}$ & $\begin{array}{c}15 / 60 \\
22 / 62.9\end{array}$ & 0.652 & $\begin{array}{c}8 / 32 \\
14 / 40\end{array}$ & $\begin{array}{l}17 / 68 \\
21 / 60\end{array}$ & 0.526 & $\begin{array}{c}5 / 20 \\
9 / 25.7\end{array}$ & $\begin{array}{c}20 / 80 \\
26 / 74.3\end{array}$ & 0.606 \\
\hline $\begin{array}{l}\text { Grade } \\
\text { Low } \\
\text { Moderate } \\
\text { High }\end{array}$ & $\begin{array}{c}0 / 0 \\
5 / 23.8 \\
9 / 29\end{array}$ & $\begin{array}{c}2 / 25 \\
5 / 23.8 \\
2 / 6.5\end{array}$ & $\begin{array}{c}6 / 75 \\
11 / 52.4 \\
20 / 64.5\end{array}$ & 0.153 & $\begin{array}{c}0 / 0 \\
7 / 33.3 \\
15 / 48.4\end{array}$ & $\begin{array}{c}8 / 100 \\
14 / 66.7 \\
16 / 51.6\end{array}$ & 0.028 & $\begin{array}{c}0 / 0 \\
5 / 23.8 \\
9 / 29\end{array}$ & $\begin{array}{c}8 / 100 \\
16 / 76.2 \\
22 / 71\end{array}$ & 0.248 \\
\hline $\begin{array}{l}\text { Type } \\
\text { Serous } \\
\text { Endometrioid } \\
\text { Mixed }\end{array}$ & $\begin{array}{c}11 / 25 \\
2 / 18.2 \\
1 / 20\end{array}$ & $\begin{array}{c}7 / 15.9 \\
2 / 18.2 \\
0 / 0\end{array}$ & $\begin{array}{c}26 / 59.1 \\
7 / 63.6 \\
4 / 80\end{array}$ & 0.945 & $\begin{array}{c}18 / 40.9 \\
2 / 18.2 \\
2 / 40\end{array}$ & $\begin{array}{c}26 / 59.1 \\
9 / 81.8 \\
3 / 60\end{array}$ & 0.438 & $\begin{array}{c}11 / 25 \\
2 / 18.2 \\
1 / 20\end{array}$ & $\begin{array}{c}33 / 75 \\
9 / 81.8 \\
4 / 80\end{array}$ & 0.999 \\
\hline $\begin{array}{l}\text { Tumor size } \\
\leq 10 \mathrm{~cm} \\
>10 \mathrm{~cm}\end{array}$ & $\begin{array}{l}7 / 17.5 \\
7 / 38.9\end{array}$ & $\begin{array}{l}7 / 17.5 \\
2 / 11.1\end{array}$ & $\begin{array}{c}26 / 65 \\
9 / 50\end{array}$ & 0.229 & $\begin{array}{c}15 / 37.5 \\
7 / 38.9\end{array}$ & $\begin{array}{l}25 / 62.5 \\
11 / 61.1\end{array}$ & 0.920 & $\begin{array}{l}\text { 7/ } 17.5 \\
7 / 38.9\end{array}$ & $\begin{array}{l}33 / 82.5 \\
11 / 61.1\end{array}$ & 0.102 \\
\hline $\begin{array}{l}\text { Distant } \\
\text { metastasis } \\
\text { Absent } \\
\text { Percent }\end{array}$ & $\begin{array}{l}11 / 22 \\
3 / 30\end{array}$ & $\begin{array}{c}9 / 18 \\
0 / 0\end{array}$ & $\begin{array}{c}30 / 60 \\
7 / 70\end{array}$ & 0.424 & $\begin{array}{c}18 / 36 \\
4 / 40\end{array}$ & $\begin{array}{c}32 / 64 \\
6 / 60\end{array}$ & 1.000 & $\begin{array}{l}11 / 22 \\
3 / 30\end{array}$ & $\begin{array}{c}39 / 78 \\
7 / 70\end{array}$ & 0.685 \\
\hline
\end{tabular}


was negative in 31 cases and positive in 29 cases (Figure 3). MMP-9 stromal staining values were compared with parameters such as disease stage, grade, histological type and tumour size; no significant difference was observed. DFS was significantly shorter in patients with stromal MMP-9 expression than the patients without expression (23 months vs 45 months; 95\% CI; p=0.0326) (Figure 4). The patients with stromal MMP-9 expression had relapsed significantly earlier than the patients without stromal MMP-9 expression. However, the same result was was not observed on OS analysis, and no statistically OS difference was observed in patients with and without stromal MMP-9 expression.

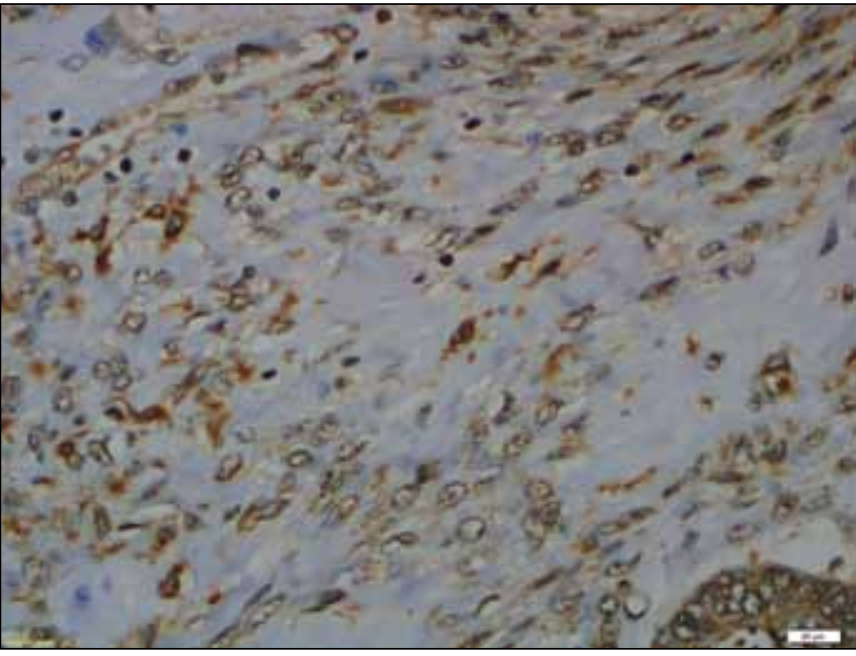

Figure 3: Stromal MMP- 9 expression in serous adenocarcinoma (MMP-9 x400).

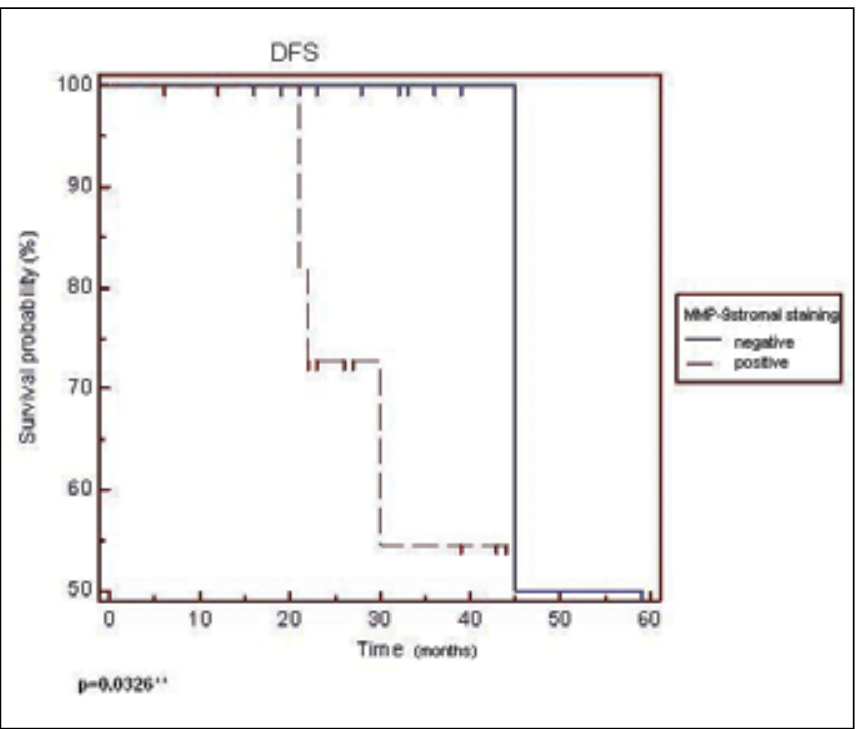

Figure 4: Kaplan-Meier survival curves for DFS of epithelial ovarian cancer patients according to stromal positivity of MMP-9.

\section{DISCUSSION}

In this study, all clinicopathological parameters were analysed. Consistent with previous studies, recurrence risk and death rate was higher and overall survival was shorter in advanced- staged patients when compared with patients with early stage disease $(7,8,24)$.

Similar with the results of the previous studies, survivin expression did not have any relationship with stage and histological type in our study $(9,28)$. Moreover, in contrast with previous reports, survivin expression was not associated with tumour grade and disease prognosis $(9,28,29,30,31)$. This result may be due to the fact that the majority of tumours in our study group were of moderate or high grade. Similarly, no association was detected between survivin expressions and the parameters such as tumour diameter, recurrence and survival. The data obtained from the previous studies suggest that survivin expression shortens the OS and DFS periods $(28,29,30,32)$. In this study, no statistically significant result could be obtained between survivin OS and DFS periods same as study by Cohen et al. (9).

In our study, MMP-9 expression in epithelial cells was compared with parameters like stage, histological type, and tumour diameter. No statistical significance was present, which was in paralel with the findings in most studies $(24,33,34)$. However the correlation between the intensity of MMP-9 in epithelial cells and histological grade was statistically significant which was similar with the study by Sillanpää et al. (25).

Similar to epithelial MMP-9 expression, no significant relationship was observed between the stromal expression of MMP-9 and all the clinicopathological parameters as well. Kamat et al. demonstrated that stromal expression of MMP-9 was associated with advanced-staged and high-grade tumours (24). Additionally, they showed that lymph node involvement, the presence of ascites, serous morphology and suboptimal cytoreduction rates were more common in tumors with stromal expression of MMP-9. Sillanpää et al. established a significant correlation between high stromal positivity and advanced stage while they could not detect any relationship between histological grade, histological type and patient's age (25). In present study, similar to previous studies, statistically significant results were observed between MMP-9 stromal staining values and DFS times $(24,25)$. However, the correlation between stromal staining and OS period was insignificant. Ozalp et al. detected a correlation between stromal staining and shortened OS period (34). In our study, the reason for 
the statistically insignificant association between stromal staining and OS could be the notable differences in patients' follow-up periods.

In summary, this study demonstrates the following results:

- Survivin expression was not associated with clinicopathological parameters and prognosis in this study.

- The correlation between MMP- 9 staining in epithelial cells and histologic grade was significant, however, no significant impact on prognosis and OS could be demonstrated.

- Stromal expression of MMP-9 had a significantly negative effect on recurrence times, however the same effect on overall survival times could not be established.

When literature is reviewed, regarding the results obtained from survivin and MMP-9, the remarkable point is; different results had been achieved in various studies carried out on this subject and there has been no consensus yet $(9,24,25,27,28-32)$. The reasons for these contradictions might be the differences in technical usage, or differences between the antibodies, manufacturing company, clonality, incubation and dilution or several methods used in evaluation $(3,9,28,32,35)$. Furthermore, it was emphasized that, to obtain statistically significant results, studies have to be carried out on a broad range of patient groups by using standardized methods $(9,18)$.

Thus, in order to prove the predictive effect of the stromal expression of MMP-9 in epithelial ovarian carcinoma treatment, retrospective and prospective studies on more homogenous and broader patient groups are clearly required.

\section{REFERENCES}

1. Jemal A, Siegel R, Ward E, Murray T, Xu J, Smigal C, Thun MJ. Cancer statistics, 2006. CA Cancer J Clin. 2006; 56: 106-30.

2. Cannistra SA. Cancer of the ovary: N Engl J Med. 2004; 351: 2519-29.

3. Lin CK, Chao TK, Yu CP, Yu MH, Jin JS. The expression of six biomarkers in the four most common ovarian cancers: Correlation with clinicopathological parameters. APMIS. 2009; 117: 162-75.

4. Crum CP, Lee KR. Diagnostic gynecologic pathology. Elsevier Saunders; 2006. 24-28: 793- 838.

5. Zhao Y, Zong ZH, Xu HM. RhoC expression level is correlated with the clinicopathological characteristics of ovarian cancer and the expression levels of ROCK-I, VEGF, and MMP9. Gynecol Oncol. 2010; 116:563-71.
6. Seidman JD, Russel P, Kurman RJ. Surface epithelial tumors of the ovary. In: Kurman RJ, editor. Blaustein's Pathology of the Female Genital Tract. 5th ed, New York: Springer; 2002. 791-904.

7. Denny L, Hacker NF, Gori J, Jones III HW, Ngan HYS, Pecorelli S. Staging classifications and clinical practice guidelines of gynaecologic cancers. In: Pecorelli S, YSN Hextan, Hacker NF, editors. Elsevier; 2000. 95- 115. (reprinted from Int J Gynecol Obstet 70:207-312, 2000).

8. Ayhan A, Başaran M. Epitelyal over kanserleri. In: Guner H editor. Jinekolojik onkoloji. 3rd ed. Ankara: Cağdaş Tip Kitabevi; 2002. 14: 201- 243.

9. Cohen C, Lohmann CM, Cotsonis J, Lawson D, Santoianni R. Survivin expression in ovarian carcinoma: Correlation with apoptotic markers and prognosis. Mod Pathol. 2003; 16: 574-83.

10. Ryan BM, O’Donovan N, Duffy MJ. Survivin: A new target for anti-cancer therapy. Cancer Treatment Reviews. 2009; 35:553-62.

11. Liguang Z, Peishu L, Hongluan M, Hong J, Rong W, Wachtel MS, Frezza EE. Survivin expression in ovarian cancer. Exp Oncol. 2007; 29: 121-5.

12. Ambrosini G, Adida C, Altieri DC. A novel antiapoptosis gene, survivin, expressed in cancer and lymphoma. Nat Med. 1997; 3: 917-21.

13. Altieri DC. Survivin in apoptosis control and cell cycle regulation in cancer. Progress in Cell Cycke Research. 2003; 5: 447- 53.

14. Zhang M, Ho A, Hammond EH, Suzuki Y, Bermudez RS, Lee RJ, Pilepich M, Shipley WU, Sandler H, Khar LY, Pollack A, Chakravarti A. Prognostic value of survivin in locally advanced prostate cancer: Study based on RTOG 8610. Int J Radiat Oncol Biol Phys. 2009; 73:1033-42.

15. Hui W, Zan Y, Wang X, Kang H, Guan H, Ma X. Expression of Survivin, p53 and its relationship with apoptosis, proliferation in hepatocellular carcinoma (HCC). Journal of Nanjing Medical University. 2008; 4:255-259.

16. Baytekin F, Tuna B, Mungan U, Aslan G, Yorukoglu K. Significance of P-glycoprotein, p53, and survivin expression in renal cell carcinoma. Urol Oncol. 2011; 29:502-7.

17. Erkanli S, Bolat F, Kayaselcuk F, Demirhan B, Kuscu E. COX2 and survivin are overexpressed and positively correlated in endometrial carcinoma. Gynecol Oncol. 2007; 104: 320-5.

18. Komuro Y, Watanabe T, Tsurita G, Muto T, Nagawa H. Survivin expression in ovarian carcinoma: Correlation with apoptotic markers and prognosis. Mod Pathol. 2004; 17: 264.

19. Zaffaroni N, Pennati M, Colella G, Perego P, Supino R, Gatti L, Pilotti S, Zunino F, Diadone MG. Expression of the anti-apoptotic gene survivin correlates with taxol resistance in human ovarian cancer. Cell Mol Life Sci. 2002; 59:1406- 12.

20. MacKeigan JP, Murphy LO, Blenis J. Sensitized RNAi screen of human kinases and phosphatases identifies new regulators of apoptosis and chemoresistance. Nat Cell Biol. 2005; 7: 591-600.

21. Davidson B, Goldberg I, Berner A, Kristensen GB, Reich R. EMMPRIN (extracellular matrix metalloproteinase inducer) is a novel marker of poor outcome in serous ovarian carcinoma. Clin Exp Metastasis. 2003; 20:161-9. 
22. Apakkan Aksun S, Ozmen D, Bayındır O. Metalloproteinazlar, inhibitörleri ve ilişkili fizyolojik ve patolojik durumlar. T Klin Tip Bilimleri. 2001; 21:332-42.

23. Sakata K, Shigemasa K, Nagai N, Ohama K. Expression of matrix metalloproteinases (MMP-2, MMP-9, MT1-MMP) and their inhibitors (TIMP-1, TIMP-2) in common epithelial tumors of the ovary. Int J Oncol. 2000; 17: 673-81.

24. Kamat AA, Fletcher M, Gruman LM, Mueller P, Lopez A, Landen CN Jr, Han L, Gershenson DM, Sood AK. The clinical relevance of stromal matrix metalloproteinase expression in ovarian cancer. Clin Cancer Res. 2006; 12: 1707-14.

25. Sillanpää S, Anttila $M$, Voutilainen $K$, Ropponen $K$, Turpeenniemi-Hujanen T, Puistola U, Tammi R, Tammi M, Sironen R, Saarikoski S, Kosma VM. Prognostic significance of matrix metalloproteinase-9 (MMP-9) in epithelial ovarian cancer. Gynecologic Oncology. 2007; 104: 296-303.

26. Cowden Dahl KD, Symowicz J, Ning Y, Gutierrez E, Fishman DA, Adley BP, Stack MS, Hudson LG. Matrix metalloproteinase 9 is a mediator of epidermal growth factor-dependent e-cadherin loss in ovarian carcinoma cells. Cancer Res. 2008; 68: 4606-13.

27. Davidson B, Goldberg I, Gotlieb WH, Kopolovic J, Ben-Baruch G, Nesland JM, Berner A, Bryne M, Reich R. High levels of MMP2, MMP-9, MT1-MMP and TIMP-2 mRNA correlate with poor survival in ovarian carcinoma. Clin Exp Metastasis. 1999; 17: 799-808.

28. Kleinberg L, Flørenes VA, Silins I, Haug K, Trope CG, Nesland JM, Davion B. Nuclear expression of survivin is associated with improved survival in metastatic ovarian carcinoma. Cancer. 2007; 109: 228-38.
29. Takai N, Miyazaki T, Nishida M, Nasu K, Miyakawa I. Expression of survivin is associated with malignant potential in epithelial ovarian carcinoma. Int J Mol Med. 2002; 10: 211-6.

30. Athanassiadou P, Grapsa D, Athanassiades P, Gonidi M, Athanassiadou AM, Tsipis A, Patsouris E. The prognostic significance of COX-2 and survivin expression in ovarian cancer. Pathol Res Pract. 2008; 204: 219-41.

31. Yin RT, Peng ZL, Yang KX, Kang DY. Survivin expression in ovarian carcinoma. Sichuan Da Xue Xue Bao Yi Xue Ban. 2006; $37: 215-217,233$.

32. Yoshida H, Ishiko O, Sumi T, Matsumoto Y, Ogita S. Survivin, bcl-2 and matrix metalloproteinase-2 enhance progression of clear cell- and serous-type ovarian carcinomas. Int J Oncol. 2001; 19:537-42.

33. Alshenawy HA. Immunohistochemical expression of epidermal growth factor receptor, E-cadherin, and matrix metalloproteinase-9 in ovarian epithelial cancer and relation to patient deaths. Ann Diagn Pathol. 2010; 14:387-95.

34. Ozalp S, Tanir HM, Yalcin OT, Kabukcuoglu S, Oner U, Uray M. Prognostic value of matrix metalloproteinase- 9 (gelatinase-B) expression in epithelial ovarian tumors. Eur J Gynaecol Oncol. 2003; 24: 417-20.

35. Tringler B, Lehner R, Shroyer AL, Shroyer KR. Immunohistochemical localization of survivin in serous tumors of the ovary. Appl Immunohistochem Mol Morphol. 2004; 12:40-3. 